\title{
A review of the potential therapeutic and cosmetic use of propolis in topical formulations
}

\author{
Mônica Valero da Silva*, Nélio Gomes de Moura Jr, Andrea Barretto Motoyama, Vania Moraes Ferreira \\ Department of Pharmacy, University of Brasilia, Darcy Ribeiro University Campus, 70.910-900 Brasília, Brazil.
}

\author{
ARTICLE INFO \\ Received on: $14 / 10 / 2018$ \\ Accepted on: 01/08/2019 \\ Available online: 03/01/2020

\section{Key words:} \\ Oxidative stress, topical \\ formulation, propolis, \\ therapeutic properties, bee \\ species.
}

\begin{abstract}
A good deal of research has been carried out on the establishment and characterization of antioxidants and antibacterial products from natural sources for topical use. Recently, investors mainly from the cosmetics industry have become interested in products from different species, not only for their individual active principles but also in the crude extract itself. Propolis is one of such products. Several previous reports have demonstrated the antimicrobial, antiinflammatory, and wound healing effects of propolis. Additionally, what has drawn attention of the pharmaceutical industry to propolis and its derivatives, such as throat spray, is related to its antioxidant properties, having the potential for treatment and prevention of oxidative stress-mediated diseases, such as those developed on the skin, as well as aging. This literature review will focus on propolis composition and related potential uses in topical pharmaceutical and cosmetic formulations.
\end{abstract}

\section{INTRODUCTION}

Propolis is a multicomponent hard resin found in beehives from certain bee species, such as Apis mellifera, which has been employed extensively since ancient times. Propolis itself comes from the Greek language and means "pro" = defense, and "polis" = city. In fact, the bees use propolis to seal off holes in their honeycombs and thus protect it from intruders, as well as to fight off microorganisms. The ancient civilizations already knew the properties of propolis and its popular use for medicinal purposes dates back from 300 A.C. (Park et al., 2005). Egyptians benefited from the anti-putrefactive properties of propolis to embalm their dead. Greek and Roman physicians used propolis as an antiseptic and healing agent. Incas employed propolis as an antipyretic agent. British pharmacopoeias of the 17th century listed propolis as an official drug. Dissecting the immunomodulatory, anti-inflammatory, antimicrobial, and antioxidant properties of propolis, and mechanisms thereof, has ensured that it is still used today both in food and cosmetic formulations (Baltas et al., 2016;

\section{${ }^{*}$ Corresponding Author}

Mônica Valero da Silva, Department of Pharmacy, University of Brasilia, 70.910-900,Brasilia, Brazil.E-mail: mvalero2@unb.br
Chan et al., 2013; Marquele et al., 2006; Oršolić et al., 2014). In this view, propolis continues to be used today as a popular remedy, and it is now available in either pure form or combined with other natural products in cosmetics and health-oriented types of food (Ferreira et al., 2017; Sforcin and Bankova, 2011). It is expected that propolis will be ever more present in the cosmetic and pharmaceutical industry.

The skin acts as a biological barrier, protecting the body's organs against external environmental hazards from diversified agents including biological (fungi and bacteria), chemical (toxic chemicals and ozone), and physical (ultraviolet radiation) ones. Thus, because of its function, the skin is considered a target organ under constant oxidative stress (Dunn and Kool, 2013) and tissue damage. In normal, intact cells, there is a balance in the production of reactive oxygen species (ROS) from the mitochondria and the expression of antioxidant enzymes including catalase, superoxide dismutase, and glutathione peroxidase. However, when a cell is under stress, this balance is disrupted and free radicals may alter cellular behavior (Ndiaye et al., 2011), leading to cell damage and death.

Both synthetic and natural medicine can be topically applied to the skin so that the active ingredients in the formula can be released. Propolis contains several components that can be simultaneously released into the skin. Therefore, it is difficult to isolate only one active agent to be evaluated in research 
protocols. In some cases, the observed biological activity seems to be the result of a synergistic effect from several components of propolis, rather than a single one. Among many available natural sources, researchers have considered propolis to be the best herbal alternative in worldwide studies for topical inflammation and other topical diseases (Bankova et al., 2014).

Considering the scientific interests in this matter, this study presents a review on propolis activities that can be useful and/or desirable for topic formulations such as antioxidant, antimicrobial, and wound healing promoting properties. These characteristics make it a very interesting target for investment in topical pharmaceutical formulations.

\section{PROPOLIS NATURAL SOURCES}

Propolis is a hard resin generally composed of approximately 50\% resin and balsam, 30\% wax, 10\% essential and aromatic oils, $5 \%$ pollen, and $5 \%$ various other substances. Propolis is derived from different plant parts, such as buds, flowering buds, and resinous exudates, which are collected from bees and taken to be used in the beehive (Sforcin, 2016). It is interesting to note that propolis produced in the northern hemisphere is resultant from bee activity during spring, summer, and the beginning of autumn, which may result in composition differences due to seasonality. On the other hand, due to a less rigorous climate, bees in the southern hemisphere collect and produce propolis throughout the year. Even then, there may be differences in composition in propolis produced at different times of the year. In fact, working with propolis collected in the southern state of Parana, Brazil, Calegari et al. (2017) reported that the contents of the propolis collected in March-June 2013 and in March 2015 were different. The former had more total phenolic compounds which correlated with a stronger antioxidant activity. This was observed by using high-performance liquid chromatography (HPLC) with Diodearray detection, total phenolic content, total flavonoid content, antioxidant activity by 2,2-diphenyl-1-picrylhydrazyl-hydrate (DPPH) and 2,2'-azino-bis (3-ethylbenzothiazoline-6-sulphonic acid), and ferric reducing antioxidant power methods. The observed changes, as proposed by the authors (Calegari et al., 2009), were due to lower bee activity, which in turn was a result from colder average temperatures $\left(5^{\circ} \mathrm{C}-6^{\circ} \mathrm{C}\right)$ between the months of March-June. Additionally, due to the enormous biodiversity of South America, the varied composition makes it difficult to pinpoint the origin of a particular propolis.

Propolis is thus most often known according to its geographical location of origin, such as Brazilian, Greek, and Indian propolis (Wang et al., 2016). However, other classifications are also possible such as the ones based on color (such as green, brown, and red propolis), as well as on agricultural characteristics ("organic" propolis). Other authors (Zhang et al., 2016) have classified propolis according to the region/flora that is the origin of propolis. As such, there can be seven types of propolis, according to the plant sources, including poplar propolis (Populus spp.), Eucalyptus propolis (AbuMellal et al., 2012), Baccharis propolis (dos Santos Pereira et al., 2003) (Brazilian green propolis), Clusia (Hernandez et al., 2005) (Brazilian red propolis), Macaranga propolis (Huang et al., 2007) (Taiwanese green propolis), Betula propolis, and Mediterranean propolis (Popova et al., 2010).
In Brazil, the plants that most often contribute to the composition of Brazilian propolis are: "assa-peixe" (Vernonia polyanthes), "aroeira" or "aroeira-salso" (Schinus molle L.), Eucalyptus, and the field rosemary (Baccharis dracunculifolia), plants found in several regions of Brazil, especially in the south, and which give origin to the so-called "green propolis" (Cordeiro et al., 2015; De Funari et al., 2007). However, due to the size of the country, differences can be found in the plants used to produce propolis, which in turn, will result in different types of propolis. For instance, from the swamps of the states of Alagoas, Sergipe, Bahia, Pernambuco, and Paraíba, all in the northeast region of Brazil, the red propolis can be found. It is derived mostly from Dalbergia ecastophyllum, a leguminous plant that gives origin to the reddish color in propolis (Huang et al., 2014). Propolis composition variations were also reported by Ferreira et al. (2017). These authors performed biochemical analyses of a propolis type that is derived from a plant popularly known as "jurema preta" [Mimosa tenuiflora (Wild.) Poir., syn. Mimosa hostilis Benth.] found in the Brazilian northeaster state, Rio Grande do Norte. This type of propolis was characterized as been low in wax and high in polyphenols and flavonoids, but with chemical constituents that make it different from the common "green propolis" or Brazilian propolis. These differences may be attributable to the main plant of origin.

Another example comes from Greece, in the work by Kasiotis et al. (2017). These authors tested eight different types of propolis obtained from different regions of Greece. Although some of the constituents were common to all types such as pinocembrin, others were found exclusively in one or two types, potentially serving as "fingerprint" constituents - for instance, eudesmic acid for propolis from Amorgos and heptacosane for propolis from Nafplio. Taken together, these results highlight the importance of the local flora to propolis composition.

In other countries, other plants are the main contributors to propolis formulation. In Russia, the main plant source of propolis is Betula verrucosa, whereas in Cuba and Venezuela, it is Clusia spp. (Sforcin, 2016).

\section{CHEMICAL COMPOSITION OF PROPOLIS}

The diverse natural source of propolis has to some extent precluded the establishment of a "common propolis formulation" with well-defined components. Most importantly, depending on the season and also on the region from where it is being collected, it may vary. What seems to be consistent when several types of propolis were analyzed is that they all have a certain amount of total phenolic compounds and total flavonoids (Table 1). Additionally, higher phenolic and flavonoid composition has been positively correlated to the ability of free radical scavenging in propolis from Argentina, Japan, Greece, and Cyprus, but not in propolis from Morocco or Brazil. Phenolic compounds have received a good deal of attention in recent years, among the various classes of naturally occurring antioxidants, particularly because they inhibit lipid peroxidation and lipoxygenase in vitro, and show reducing properties. These characteristics play an important role in the neutralization or sequestration of free radicals and in transition metal chelation, acting both in the initiation and propagation steps of the oxidative process. The phenolic compounds of plants can be further classified into many categories like simple phenol, phenolic acids (a derivate of benzoic acids and cinnamic), 
Table 1. Total polyphenol and flavonoid content of propolis from different regions and countries.

\begin{tabular}{|c|c|c|c|}
\hline Country & Total polyphenols (mg/g) & Total flavonoids (mg/g) & References \\
\hline Algeria & $55-279$ & $10-69$ & Boufadi et al. (2014) \\
\hline Argentina & $257-393$ & $66-133$ & Lima et al. (2009) \\
\hline Brazil & $94-149$ & $6-21$ & Schmidt et al. (2014) \\
\hline China & $43-302$ & $8-162$ & Ahn et al. (2007) \\
\hline Greece and Cyprus & $80-338$ & $9-183$ & Kalogeropoulos et al. (2009) \\
\hline India & 159 & 57.25 & Laskar et al. (2010) \\
\hline Japan & $53-431$ & $18-113$ & Hamasaka et al. (2004) \\
\hline Morocco & $0.74-91$ & $0.20-34$ & Popova et al. (2015) \\
\hline Portugal & $150-197$ & $36-62$ & Moreira et al. (2008) \\
\hline South Korea & $85-283$ & $16-135$ & Ahn et al. (2004) \\
\hline
\end{tabular}

Adapted from Wang et al. (2016).

coumarin, flavonoid, stilbene, condensable and hydrolyzable tannins, lignans, and lignins (Sousa et al., 2007).

Phenolic constituents and antioxidant activity of propolis from Melipona interrupta and Melipona seminigra, two species of Amazonian stingless bees from the north of Brazil were studied. Both methanol and ethanol propolis extracts from $M$. interrupta showed higher content of phenolic compounds and greater antioxidant activity in relation to extracts of propolis produced M. seminigra. The analysis of propolis species showed promising results for antioxidant activities to the prevention of diseases of the local population (Silva et al., 2013).

In recent studies, the Brazilian red propolis was characterized by Liquid Chromatography-Orbitrap-Fourier Transforming Mass Spectometry and many molecules were found such as elemicin, isolemicin, methyl isoeugenol, methyl eugenol, formononetin, biochanin A, isoliquiritigenin, medicarpin, homopterocarpan, quercetin, and vestitol that allow it to be distinguished from other types of Brazilian propolis (Mendonça et al., 2015).

Similarly, Greek propolis, from different parts of the country, has been recently reanalyzed for its biochemical composition as well as for its antioxidant potential (Kasiotis et al., 2017). Of the eight different types analyzed, the total phenolic content varied from $113-181 \mathrm{mg} / \mathrm{g}$. The total flavonoid content ranged from $46-86 \mathrm{mg} / \mathrm{g}$. The free radical scavenging activity was also measured in the same samples by the DPPH assay. By this method, IC50 values could be found to be as low as $1.19 \mu \mathrm{g} / \mathrm{ml}$ and were no bigger than $16 \mu \mathrm{g} / \mathrm{ml}$. The authors also evaluated quantitatively the constituents of the eight types of Greek propolis and over 25 different ones were found. Pynocembrin and chrysin were the only ones found in all eight types. Other components found were galangin, gallic acid, p-coumaric acid. Caffeic acid, caffeic acid phenethyl ester, and quercetin were found in five, six, and five samples, respectively.

Savka and collaborators (Savka et al., 2015) reported the analyses of eight different types of propolis, collected in different regions of the United States of America (e.g., Nevada, Minnesota, and Louisiana). These authors deliberately chose regions with differing climates, such as cold (northern regions), wet (southeast), and dry (southwest), and tested propolis samples originating from these regions. Upon gas chromatography-mass spectrophotometry analyses, they were able to categorize compounds into eight different classes. Some of them, such as cinnamic acid derivatives, were present in all samples analyzed. Others, on the other hand, such as phenolic glycerides were present only in the samples from Minnesota and New York, but not in those from Nevada, for instance.

In summary, the chemical composition of propolis is highly dependent on its region and the local flora, which in turn is directly influenced by its macro- and micro-climate. Plants found in dry versus wet, perennial versus seasonal plants will most likely give rise to different kinds of propolis. However, all of them contain varying amounts of polyphenols and flavonoids, which warrant the biological activities of propolis.

\section{PROPOLIS BIOLOGICAL ACTIVITIES}

Due to its diverse therapeutic properties, and its composition chemical richness, propolis has become a focus of interest in many areas of scientific research, seeking to discover new therapies to treat many diseases like diabetes, tumor, bacterial infections, allergic rhinitis, and ulcers. (Sforcin et al., 2011). Propolis active compounds have antibacterial, antifungal, antiviral, anti-inflammatory, antioxidant, anti-tumor, immunomodulatory, hepatoprotective, antidiabetic, and healing properties (Fig. 1) (Chan et al., 2013; Hu et al., 2005; Khalil, 2006; Marquele et al., 2005; Zhang et al., 2016). Its essential oil also contains terpenoids, aromatic and aliphatic compounds that exhibit antibacterial activity (Garedew et al., 2004; Melliou et al., 2007) and inhibits lipid peroxidation (Gregory et al., 2007; Gregory et al., 2008). In this review, we focus solely on the use of propolis topically, whether it is for therapeutic or for cosmetic purposes.

\section{Antioxidant properties}

The antioxidant activity of propolis has been observed in topical formulations to prevent and treat skin diseases, as well as aging (Fig. 1). A healthy skin depends upon the balanced presence of free oxygen radicals, of which high levels can cause cell death and aging.

Free radicals are defined as any species that contains one or more unpaired electrons, capable of existing independently (Halliwell and Gutteridge, 2016). Oxygen in its ground state has two unpaired electrons and can act as an oxidizing agent (Pietta, 2000).

In addition, ROS are generated by all aerobic cells, as by-products of various metabolic reactions and in response to different stimuli (Aliev et al., 2008; Bennett et al., 2009). Under 


Antioxidant
Activity:
Prevent skin
damage and skin
ageing and
wrinkling

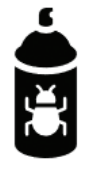

Antimicrobial

Activity:

Acne Treatment

Mycoses Treatment

\section{UV absortion: \\ Sunscreen use}

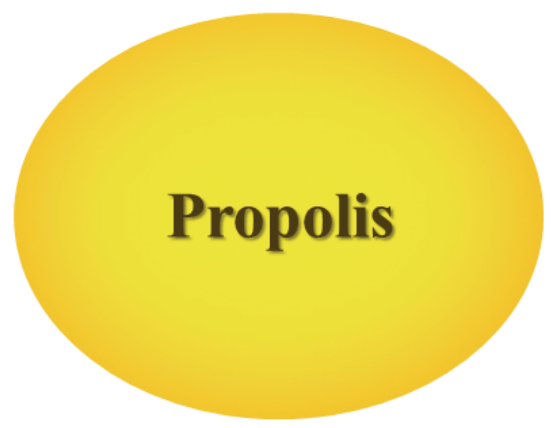

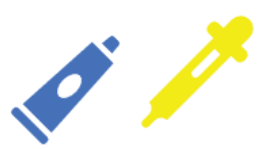

Accelerates wound closure and re-epithelization: Wound healing, including burns and diabetes-related wounds

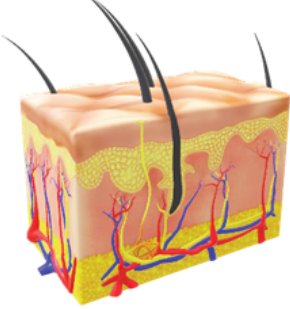
Herein the topical use of propolis and its properties are discussed, such as antioxidant, antimicrobial, cosmetic stabilizer, wound healing and sunscreen.

specific stress conditions, the ROS levels exceed the antioxidant capacity of a cell, establishing an imbalanced condition referred to as oxidative stress. This situation can be derived from a reduction in the antioxidant defense system due to the depletion of components of this system or mutations that compromise its functions. Oxidative stress can also result from the increased production of ROS due to exposure to the compounds that generate them and/or activate ROS systems and/or hypertoxic conditions or both (Costa and Moradas-Ferreira, 2001).

Polyphenols and flavonoids (the major constituents of propolis) can also act by different antioxidant mechanisms, including the inhibition of the enzymes involved in the formation of reactive oxygen species (xanthine oxidase, protein kinase $\mathrm{C}$, lipoxygenase, cyclooxygenase, and oxidation of nicotinamide adenine dinucleotide). It has also been described to chelate trace elements (free iron or copper), which are potential enhancers of the generation of free radicals, or to act even as stabilizers of these radicals involved in oxidative processes by forming complexes with them (Daleprane et al., 2013; Pietta, 2000). Even though propolis has many active compounds that have already been investigated for various organic disorders, only few reports have focused on its antioxidant biological responses in topical formulations.

A study by Mouhoubi-Tafinine et al. (2016) compared honey with propolis found in a region of Algeria, regarding its antioxidant activity. The extracts of propolis presented significantly higher activity than honey. The antioxidant activity measured through the reduction test indicated higher activity in propolis in extracts with methanol, showing the relation of phenolic components and antioxidant activity.

A functional emulsion with 11 compounds extracted from Brazilian red propolis containing echium oil (omega 3), alpha-linolenic acid, stearidonic acid, and plant sterol esters, with or without phenolic compounds, was analyzed. Oxidative markers, such as hydroperoxides, thiobarbituric acid reactive substances, and phytosterol oxidation products were evaluated. Their oxygen radical absorbance capacity was also tested. Researchers found that synapic acid and rutain, both present at high quantities in the ethanolic extract of propolis from Alagoas, a northeastern state of Brazil, showed the same antioxidant activity as tertbutylhydroquinone (standard antioxidant) and should be further investigated as a potential natural antioxidant that could be applied in a functional emulsion (Freires et al., 2016).

In addition, the antioxidant activity of propolis can be used to evaluate its functional activity in topical formulations or to evaluate the release of its active principles from such formulations. (Marquele-Oliveira et al., 2007). One of the theoretical concerns regarding phytotherapeutic research, however, has been toward the development of active ingredient release studies and formulations, when propolis components could interfere with each other, showing antagonistic or synergistic activities. In practice, these concerns could be rapidly overcome. The use of crude ethanolic, aqueous, or methanolic propolis extracts showed that synergic action seemed to enhance the results obtained when other known antioxidants were used, even if certain constituents could already present antioxidant action by themselves.

\section{Antimicrobial activity}

Several studies have shown the antimicrobial activity of virtually all types of propolis (Fig. 1). Propolis is generally considered to be more active against Gram-positive bacteria, than Gram-negative (Grange and Davey, 1990; Sforcin et al., 2000). Although the exact reason for this is not completely elucidated, it is possible that propolis may interact with lipids in the plasma 
membrane, increase membrane permeability, and inhibit bacterial motility. To do so, it must reach the cell membrane, which is more easily done in the Gram-positive microorganisms, than in the Gram-negative. Other proposed mode of action is the generation of ion imbalance in the microenvironment of the bacteria.

Seven variants of organic propolis were grouped based on the chemical profile (by HPLC) and all of them exhibited high reactive-species-scavenging activity, manly against superoxide and hypochlorous acid species. The minimal inhibitory concentration (MIC) of organic propolis ethanolic extract against Grampositive bacteria: Streptococcus mutans, Streptococcus oralis, and Staphylococcus aureus was $12.5-100 \mu \mathrm{g} / \mathrm{ml}$ while Gram-negative bacteria Pseudomonas aeruginosa was sensitive to the organic propolis with MIC values at $100-200 \mu \mathrm{g} / \mathrm{ml}$. So, organic propolis can be considered an excellent source of bioactive compounds with great potential for application in the pharmaceutical and food industry. Additionally, this kind of propolis has attracted the attention due to its mild flavor and absence of heavy metals and pesticides (Tiveron et al., 2016).

Recently, a component of brown propolis was shown to inhibit biofilm formation from the bacteria Staphylococcus aureus and from the protozoan Trichomonas vaginalis as reported by Dembogurski et al. (2018). In fact, in the concentration of $125 \mu \mathrm{g} /$ $\mathrm{ml}$, propolis fractions killed $93 \%$ of $S$. aureus. The MIC against $T$. vaginalis was $400 \mu \mathrm{g} / \mathrm{ml}$, demonstrating its antimicrobial activity.

Several reports have shown the antimycotic activity of propolis both in vitro and in vivo against different pathogenic fungi. It has effectively inhibited conidia germination of Aspergillus flavus with propolis ethanolic extract at 1-4 g/l (Ghaly et al., 1998), and the growth of C. albicans with $0.5 \mathrm{mg}$ of propolis extract in 70\% ethanol (Bankova et al., 1999; Kujumgiev et al., 1999), as well as other species of Candida (Capoci et al., 2015; Ota et al., 2001). In some cases, it was investigated whether the activity was fungicidal or fungistatic (Siqueira et al., 2015).

Other works have shown that some components of propolis may be crucial for its antifungal activity, such as reported by Boisard et al. (2015). In their work, they tested French propolis against samples of human pathogenic fungi ( $C$. albicans, $C$. glabrata, and Aspergillus fumigatus) and realized that the activity against Candida spp was correlated with the flavonoid content of propolis. The MIC against C. albicans and C. glabrata was between 16 and $31 \mu \mathrm{g} / \mathrm{ml}$; however, the MIC against $A$. fumigatus was $250 \mu \mathrm{g} / \mathrm{ml}$. The inhibition of Candida sp growth was also observed in the biofilm formation from patients' samples from vulvovaginal candidiasis, suggesting that this type of infection could also potentially be treated with propolis. The concentration of $546.87 \mu \mathrm{g} / \mathrm{ml}$ from the propolis extractive solution was able to cause the death of 75.8\% isolates of Candida (Capoci et al., 2015).

More impressively, in a specific formulation, propolis was able to inhibit in vitro the growth of azole-resistant isolates of C. albicans, C. glabrata, and C. krusei. Four samples of ethanolic propolis extract were tested and the highest activity was found in sample 2 with minimum fungicidal concentration values in the range from $0.156 \%$ to $1.25 \%(\mathrm{v} / \mathrm{v})$ (Szweda et al., 2015). This is of great relevance, considering that fungal infections are among the most difficult types to eradicate, even with modern, combined therapeutic options available today. In fact, most antifungal therapy is accompanied by severe side effects, such as renal failure, and severe skin rashes, all of which are not observed with propolis (Brunton et al., 2018).

In a clinical study with 16 patients (Morawiec et al., 2015), propolis was applied as a gel in patients who had undergone a common oral surgery procedure such as molar extraction and implant installation. The use of the ethanolic extract of propolis enriched gel at 3\% reduced the presence of microorganisms, such as Neisseria spp, Bifidobacterium spp, and eliminated $S$. oralis, S. epidermalis, and Vellonella parvula, among others. Several reports have demonstrated, in clinical practice, that propolis can be at least as good as chlorhexidine as an antiseptic mouthwash (Akca et al., 2016; Santiago et al., 2018), and it can cause regression of chronic periodontitis (Cairo do Amaral et al., 2006) and gingivitis (Bretz et al., 2014; Cairo do Amaral et al., 2006). In two separate studies (Bhat et al., 2015; Ercan et al., 2015), propolis was shown to effectively reduce plaque formation. These studies have propelled clinical trials using propolis as a mouthwash to prevent plaque formation and gingivitis (NCT01750801 and NCT03553628).

\section{Propolis in wound healing}

It has been suggested that the use of propolis in wound healing may be beneficial, not only because of its antimicrobial properties but also for the skin reconstitution itself (Fig. 1) (Oryan et al., 2018) Jacob et al. (2015), for instance, evaluated the effects of Malaysian and Brazilian red propolis on connective tissue fibroblasts. Propolis enhanced cell proliferation and growth capacity. It also induced the production of collagen types I and III, concomitantly to wound matrix degradation. Taken together, these biochemical changes could favor re-epithelization and thus represent promising actions in wound healing.

These biochemical properties on the damaged skin have a direct potential use in prevalent problems related to healing wounds, such as those arising from burns and diabetes.

Han et al. (2005) studied the effect of $50 \%(\mathrm{v} / \mathrm{v})$ propolis cream and silver sulfadiazine in the healing of burned wounds in rats. A burned model was constituted on the back of rats, subjected to a $1 \mathrm{~cm}$ diameter surface area full-thickness third-degree skin burns by the brass probe. After 10 and 21 days of treatment, the burned skin tissue was collected. It was observed that $50 \%$ propolis cream was effective in healing burned skin wounds. Similar results were observed in studies with propolis ointments that showed its effectiveness to treat skin burns. It was suggested that this effectiveness is likely due to its healing, anesthetic, antimicrobial, antibacterial, and anti-inflammatory properties (Pessolato et al., 2011). Therefore, the use of propolis may be effective in treating second-degree burns in all stages of healing.

During skin burning, free radicals are formed and the choice of drugs must be appropriate. Propolis seems to be an optimal agent for the treatment of thermal injuries due to its properties discussed above. The benefits of propolis have been widely used in dermatology for healing injuries, reduction of healing time, wound contraction increase, tissue repair acceleration, thermal damage, and external ulcers therapy. The components responsible for this activity are flavonoids, phenolic acids, and their esters (Olczyk et al., 2013).

In a type I diabetic mouse model, propolis was shown to accelerate wound closure by promoting transforming growth factor- 
beta expression and its downstream signaling (Hozzein et al., 2015). In this model, deposition of collagen type I was found increased, and matrix metalloproteinases activity, as well as inflammation, were decreased.

Another use for the activity of wound healing of propolis was recently reported by Moon et al. (2018). These authors worked with 130 patients who had undergone tonsillectomy or adenotonsillectomy and were randomly assigned to groups that received either treatment with topical propolis formulation, or placebo. The research studies scored for bleeding and pain during a 10-day follow-up. The group receiving propolis application showed significantly less pain on postoperative days 3 and $7-10$, better wound healing on days 7-10, and overall less hemorrhage than the placebo group.

Afkhamizadeh et al. (2018) reported a clinical trial to test the use of propolis $(5 \%)$ ointment. Patients with diabetic ulcers were randomly assigned to either of the two treatment groups: conventional treatment alone or conventional treatment in combination with a $5 \%$ propolis ointment and were followedup for 4 weeks. Patients that underwent combined treatment showed faster-wound healing, as significant differences were found in weeks 1 and 2, between the two groups. At later stages (week 4), the groups showed no significant statistical difference. The authors also reported that although the changes in erythema and ulcer discharge were not significantly changed, the ulceration area was decreased and the wound healing process was enhanced within 4 weeks after topical administration of 5\% propolis ointment. These results indicate that propolis could speed the wound healing process.

In addition, propolis seems to be safe for use for type 2 diabetic patients. The effect of the Brazilian green propolis was evaluated in a group of 70 patients with diabetes mellitus for 18 weeks, in a randomized controlled study, consisting of a test group $(n=32)(900 \mathrm{mg} /$ day $)$ and a control group $(n=33)$, taking propolis orally. The results showed no significant difference in serum glucose, glycosylated hemoglobin, insulin, aldose reductase, or adiponectin between the two groups. However, serum glutathione and total polyphenols were significantly increased, and serum carbonyls and lactate dehydrogenase activity were significantly reduced in the Brazilian green propolis group (Zhao et al., 2016). These results, nonetheless, must be taken cautiously, as the administration form was oral (vs. topical), and the number of patients, small. At first glance, propolis use by diabetic patients, especially as topical formulation, where absorption may be incomplete, and thus may not affect important biochemical parameters such as glucose and insulin levels. It still remains to be seen, however, how other parameters would respond, both with oral and topical formulations, during an intermediate or long treatment.

Overall, these data indicate the use of topical formulation with propolis may enhance/speed the process of wound healing, with potential gain in difficult and delicate cases such as wounds related to burns and diabetes.

\section{USE OF PROPOLIS IN COSMETIC FORMULATIONS}

\section{Activity of propolis in photoprotector products}

Ultraviolet (UV) light exposure may lead to various skin diseases, such as premature aging of the skin (wrinkling, scaling, dryness, dilatation of blood vessel, and loss of collagen) and skin cancer (Nichols and Katiyar, 2010). Propolis, due to its high antioxidant activity, has been shown to have protective and preventive characteristics, which places products containing propolis in the cosmeceutical class, with possible use in commercial formulations for sun protection.

The main constituents of propolis, as discussed above, are polyphenols and flavonoids. Polyphenols are promising because they are characterized by an absorption spectrum that can filter UV radiations so reducing the penetration of the radiations into the skin and consequently lowering inflammation, oxidative stress, and DNA damaging effect (Gregoris et al., 2011). Flavonoids are capable of absorbing UV rays, which underscores the possibility of its usage as a sunscreen in photoprotectors. Two interesting studies have addressed the photoprotection potential of propolis.

Nascimento et al. (2009) evaluated two types of propolis (green and red) for their photoprotective action (Fig. 1). Both green and red propolis absorbed light in the UV region, with the green propolis having higher values of absorption in the UV region than the red propolis. The greater degree of potential photoprotection in the green propolis in comparison to the red propolis may be related to its chemical composition, fauna and flora of the region, chemical interaction between the plant metabolites, and the chemical constituents of the formulation employed in the study (Nascimento et al., 2009; Nichols and Katiyar, 2010).

Gregoris et al. (2011) used the ethanolic extract of raw propolis samples coming from the Veneto region, Italy. These authors measured the content of polyphenols, the antioxidant activity (as lipid peroxidation), as well as the sun protection factor a specific propolis formulation. The latter activity was measured as recommended by the Food and Drug Administration, using an in vitro model and a CIBA sunscreen simulator - their methodology is explained in detail in their paper. The samples tested resulted in good protection to ultraviolet radiation (UVR), which was higher than the UVR filters available in the skincare market. It should be noted that synthetic sunscreens tend to have too much $\mathrm{TiO}_{2}$, which can generate dangerous free radicals (Gasparro et al., 1998). Propolis, on the other hand, not only does not generate free radicals but rather can control their levels, by its antioxidant activity. Taken together, the studies suggest that propolis and its components, due to its UVR protection and antioxidant activity, may be view as a cosmeceutical, and will probably be increasingly more used in cosmetics.

\section{Use of propolis in acne}

Propolis can be used to treat acne due to its antimicrobial, anti-inflammatory, and healing properties. As a result of the increased resistance of bacteria to antibiotics, the use of natural products has become an alternative for topical treatment of various pathologies such as bacterial acne. According to Barbosa et al. (2014), the tincture of propolis was able to inhibit microbial growth. Propolis resin, for example, found in plants visited by bees in the region of Ponta Grossa (Paraná, Brazil) is constituted of essential oils with flavonoids. Additionally, compounds such as caffeic acid, phenolic ester of caffeic acid, quercetin, and naringenin act as suppressors of prostaglandins, leukotrienes, and inhibit the generation of nitric oxide; they also remove free radicals generated by the neutrophils responsible for the antioxidant activity, reducing inflammation (Barbosa et al., 2014; 
Matsuchita and Matsuchita, 2014). Tincture of propolis 20\% from Rosmarinus officinalis was used in different concentrations in the latter work, and some of them $(10.0 \% ; 5.0 \% ; 2.5 \% ; 1.25 \%$; $0.0625 \%$ ) showed antibacterial activity against $P$. acnes using the macrodilution method. The minimum inhibitory concentration was $0.625 \%$. Due to propolis present cicatrizing activity, the use of propolis in cosmetic formulations for topical treatment has been suggested (Barbosa et al., 2014).

Dzialo et al. (2016) studied the phenolic compounds and their potential in therapy of skin disorders. This work showed that due to their natural origin and low toxicity, phenolic compounds are a promising tool in eliminating the cause and effects of skin aging, skin diseases, and skin damage. Polyphenols also act protectively and help prevent or attenuate the progression of certain skin disorders like wrinkles and acne or serious, potentially life-threatening diseases such as cancer.

\section{Use of propolis in lipstick}

In line with the use of more natural products rather than chemical ones, Goik et al. (2015) tested a lipstick formulation using propolis. These authors evaluated the effect on the rheological and texture properties of this cosmetic without using synthetic compounds, preservatives, fragrances, and dyes. The texture analysis indicated that lipsticks with propolis at $10 \mathrm{~g} / \mathrm{kg}$ are more fragile and prone to crushing. There was no change in rheological behavior; it was viscoelastic before and after the addition of propolis (Goik et al., 2015). However, a temperature increase $\left(30^{\circ} \mathrm{C}\right)$ did not cause significant changes in their textures. If propolis is used as an ingredient in the composition of a cosmetic, it may make a difference in the quality and purpose of use of these products, which can now be directed to outdoor activities, sports, as well as tropical countries, where regular temperatures are already high. Undoubtedly, cosmetics are an important economic area, and nowadays many costumers look for high quality in this kind of products.

\section{USE OF PROPOLIS IN PHARMACEUTICAL FORMULATION}

There are some studies about the use of propolis in pharmaceutical formulation. In the area of nanoparticles, there is a study about the immunological activity of propolis flavonoids liposome in vitro and in vivo. The propolis was extracted with ethanol $95 \%$ and then dried in vacuum to obtain flavonoids. The propolis flavonoids liposome was prepared with ethanol injection method and the encapsulation efficiency was $91 \%$. This study found valuable information regarding the possibility of the use of propolis flavonoids liposome as a potential adjuvant in the immune modulatory function (Tao et al., 2014).

Microemulsion and nanoemulsion using propolis as active ingredient consist other possibilities in pharmaceutical formulations. Zilius et al. (2016) formulated microemulsion using PEG-8 caprylic/capric glycerides (Labrasol) and ethanolic propolis extracts, aiming at delivering propolis phenolic compounds ex vivo in to the skin. Their results with this $\mathrm{o} / \mathrm{w}$ microemulsion were interesting because the phenolic compounds were found predominantly in the lipid phase of microemulsion minimizing their availability at the surface of the skin. In this light, they considered this formulation as potential antioxidant that could be applied for reduced deleterious effects of oxidative stress on biological systems (Zilius et al., 2016).

A work with nanoemulsions based on aqueous propolis and lycopene extract was conducted to evaluate the harmlessness of the propolis-lycopene system and to determine the photoprotection capacity of natural substances in nanoemulsion. This work was performed through the evaluation of level skin changes and antiinflammatory action. Aqueous extract of propolis was obtained by refluxing $100 \mathrm{~g}$ of propolis powder and $250 \mathrm{ml}$ of water, lycopene was obtained from ripe tomatoes. The nanoemulsions were prepared with both substances and the results showed that this system exhibited moisturizer characteristic that improves the ability of the skin to defend against sunlight (Butnariu and Giuchici, 2011).

Novel aqueous formulation of propolis spray was evaluated for its topical anti-inflammatory activity in comparison with two other commercial propolis-based sprays, a hydroalcohol spray and hydroglyceric one used for topical treatment of inflammatory conditions of the oropharyngeal cavity. The results obtained demonstrated the topical anti-inflammatory activity of the novel aqueous formulation of Actichelated ${ }^{\circledR}$ propolis in comparison with two commercial formulations (Sosa et al., 2007).

Propolis formulation is used in common cold, upper respiratory tract infections, and flu-like infection. A study (Shinmei et al., 2009) about potentials uses of propolis mention the administration of Brazilian propolis in sneezing and nasal rubbing in experimental allergic rhinitis in mice model. The authors concluded that propolis may be effective in the inhibition of histamine release. Studying 46 human patients with mild-tomoderate asthma, who used an aqueous extract of propolis $13 \%$ using for 2 months, Khayyal et al. (2003) reported a reduced incidence and severity of nocturnal attacks. Pharmaceutical

Table 2. Reported side effects of propolis (case reports).

\begin{tabular}{|c|c|c|c|c|}
\hline Authors & Publication year & Title & Case & Adverse effects \\
\hline Garrido Fernandez et al. & 2004 & $\begin{array}{l}\text { Allergic contact stomatitis due to therapeutic } \\
\text { propolis. }\end{array}$ & $\begin{array}{l}\text { Consumption of oral propolis } \\
\text { tablets. }\end{array}$ & Stomatitis (two cases) \\
\hline Pasolini et al. & 2004 & $\begin{array}{l}\text { Allergic contact cheilitis induced by repeated } \\
\text { contact with propolis-enriched honey. }\end{array}$ & Honey consumption. & $\begin{array}{l}\text { Cheilitis due to allergic } \\
\text { reaction }\end{array}$ \\
\hline Matos et al. & 2014 & $\begin{array}{l}\text { A case of allergic contact dermatitis caused by } \\
\text { propolis-enriched honey. }\end{array}$ & $\begin{array}{l}\text { 69-year-old woman used honey } \\
\text { for cosmetic purposes. }\end{array}$ & Contact dermatitis \\
\hline Nyman and Hangvall & 2016 & $\begin{array}{l}\text { A case of allergic contact cheilitis caused by } \\
\text { propolis and honey }\end{array}$ & Honey consumption. & $\begin{array}{l}\text { Cheilitis due to allergic } \\
\text { reaction }\end{array}$ \\
\hline Lamoureux et al. & 2017 & $\begin{array}{l}\text { A first case of erythema multiforme-like contact } \\
\text { dermatitis caused by propolis. }\end{array}$ & Topical use of propolis essence. & $\begin{array}{l}\text { Erythema multiforme-like } \\
\text { contact dermatitis. }\end{array}$ \\
\hline
\end{tabular}


formulation with ethanolic propolis extract and polymers like Carbopol 934P, poloxamer 407, or gelatine were designed for the treatment of oral mucosa diseases and the data obtained indicate a potentially useful role in this treatment (Wagh, 2013).

Another type of use for propolis is lozenges and toothpaste. There are reports that this kind of formulation causes acute oral mucositis with ulceration. Because of allergic reactions in some people, the use of these products should be done with care. A case report of a 77-year-old man draws attention to the side effects because at time of the examination, the tongue was reddened and painful and there was desquamation of mucosal surface of the lower lip with tags of detached tissue, and the lips were swollen and inflamed (Hay and Greig, 1990).

\section{SIDE EFFECTS OF PROPOLIS}

The uses of both oral and topical propolis has been considered overall safe, and propolis has been considered nontoxic at doses of approximately $1.4 \mathrm{mg} / \mathrm{kg}$ and day or $70 \mathrm{mg} /$ day.

It is interesting to note that the genotoxic activity that has been tested on propolis has been deemed to be non-genotoxic. The ethanolic extract of Brazilian propolis has been subjected to such studies in different models, such as Allium cepa (Roberto et al., 2016) and Chinese hamster ovary cells mammalian cells (Santos et al., 2014). In the former work, the genotoxic activity of ethanolic extract of propolis was assessed by the presence of micronuclei and chromosomal aberrations. Not only propolis did not induce genotoxic damage but also it protected against methyl methanesulfonate. The work by Santos et al. (2014) analyzed several aspects of the ethanolic extract of propolis, in addition to the genotoxic potential. This extract was considered to be nongenotoxic and even to show some protective activity against gamma-irradiation-induced DNA damage (50\% reduction). As for cytotoxicity, at lower concentrations tested $(50 \mu \mathrm{g} / \mathrm{ml})$, propolis seemed to induce cell proliferation or at least to reduce irradiationinduced necrosis. Interestingly, post-irradiation treatment with higher concentrations $(200 \mu \mathrm{g} / \mathrm{ml})$ induced necrosis at 24 and 48 hours, but not at 72 hours. Although further studies are clearly necessary, these results indicate that propolis may not be safe in all the possible settings.

There have been cases of allergies to propolis reported (Table 2). These cases are most frequently contact dermatitis, found in beehive handlers, but other reports are also available. Matos et al. (2014) reported a case of contact dermatitis at the temporal portions of the face, forehead, and cheeks of a 69-yearold woman. She had used honey for cosmetic purposes, and dermatitis was confirmed with patch application. Later, when questioned, the beekeeper/honey producer admitted adding propolis to the honey provided, as a means of preservative, due to its antimicrobial activity. Two different other cases of cheilitis due to allergic reaction to propolis (as confirmed by patch test for 3-7 days) have been reported in patients who consumed honey (Nyman and Hangvall, 2016; Pasolini et al., 2004). It should be pointed that although propolis is not commonly found in honey, the addition of propolis to this food and use in cosmetic products has been increasing. Two additional cases of stomatitis were reported by Garrido Fernandez et al. (2004) when propolis was given as oral tablets. In these cases, symptoms were resolved with glucocorticoids and anti-histaminic medication.
Whether propolis by itself could serve a sensitizing agent is debatable. Since propolis composition may vary, some types of propolis may have the potential to cause an allergic reaction, whereas others may not. It is believed that among the known components of some propolis, 3-methyl-2-butenyl-caffeate and phenyl-ethyl caffeate may play a direct role in sensitization. Other components such as benzyl salicylate and benzyl cinnamate may have a supporting role (de Groot 2013).

Propolis-induced dermatitis had previously only been known to beekeepers, and in most cases, the occurrence of such cases was underreported. A series of reports have addressed the frequency of allergic reactions both in beekeepers as well as in the general population, and the prevalence of positive patch test reactions to propolis has reached $1.9 \%-3.5 \%$. This has led the authors of these reports to advocate propolis inclusion in the baseline series (Henschel et al., 2002; Rajpara et al., 2009; Wilkinson et al., 2019). With the increasing inclusion of propolis in cosmetic products, it will be interesting to follow up the reports on allergic reactions, both in beekeepers as well as in the general population. As a final note to propolis-induced allergies, propolis, and mainly, two of its most frequently found components (pinocembrin and chrysin), have been reported to combat allergic reactions in in vitro and in vivo models. (Choi et al., 2017; Gu et al., 2017; Hanieh et al., 2017). The use of propolis to treat allergic reactions, although promising and interesting, is still incipient and falls beyond the scope of this review.

\section{FINAL CONSIDERATIONS}

Propolis may be a promising alternative in the treatment of some diseases according to a number of studies that have proven many of its therapeutic activities. Some studies, however, are still missing. For instance, it is not known if propolis could have teratogenic activity, thus preventing its usage by pregnant women. Additionally, given the existing cases of contact dermatitis, it would be beneficial to investigate whether constant exposure would increase the cases of allergic reactions, and if so, in which conditions.

On the other hand, the antioxidant, healing, antibacterial, antitumor, and anti-inflammatory activities of propolis may be more effectively used in the development of new research. Particularly, the pharmaceutical and cosmetic areas could benefit from this product, which could result in better disease treatment and the improvement of cosmetics with esthetic aspects, in regard to photoprotection and possibly make-up with anti-aging purposes. As propolis is a natural substance and with various activities, as already has been seen in existing publications, it is expected that it will be used in new pharmaceuticals and/or cosmetics available to the population, thus offering effective and safe treatment options.

\section{CONFLICT OF INTEREST}

The authors declared that they have no conflict of interest.

\section{FINANCIAL SUPPORT}

None.

\section{REFERENCES}

Abu-Mellal A, Koolaji N, Duke RK, Tran VH, Duke CC.Prenylated cinnamate and stilbenes from Kangaroo Island propolis and their antioxidant activity. Phytochemistry. 2012; 77:251-9. 
Afkhamizadeh M, Aboutorabi R, Ravari H, Fathi Najafi M, Ataei Azimi S, Javadian Langaroodi A, Yaghoubi MA, Sahebkar A. Topical propolis improves wound healing in patients with diabetic foot ulcer: a randomized controlled trial. Nat Prod Res, 2018; 32(17):2096-9.

Ahn MR, Kumazawa S, Hamasaka T, Bang KS, Nakayama T. Antioxidant activity and constituents of propolis collected in various areas of Korea. J Agric Food Chem, 2004; 52:7286-92.

Ahn MR, Kumazawa S, Usui Y, Nakamura J, Matsuka M, Zhu F, Nakayama, T. Antioxidant activity and constituents of propolis collected in various areas of China. Food Chem, 2007; 101:1383-92

Akca AE, Akca G, Topçu FT, Macit E, Pikdöken L, Özgen IŞ. The comparative evaluation of the antimicrobial effect of propolis with chlorhexidine against oral pathogens: an in vitro study. Biomed Res Int 2016; 2016:3627463.

Aliev G, Obrenovich ME, Reddy VP, Shenk JC, Moreira PI, Nunomura A, Zhu X, Smith MA, Perry G. Antioxidant therapy in Alzheimer's disease: theory and practice. Mini Rev Med Chem, 2008; 8:1395-406.

Baltas N, Yildiz O, Kolayli S. Inhibition properties of propolis extracts to some clinically important enzymes. J Enzyme Inhib Med Chem, 2016; 31(S1):52-5.

Bankova V, Popova M, Trusheva B. Propolis volatile compounds: chemical diversity and biological activity: a review. Chem Cent J, 2014; $28: 1-8$.

Bankova V, Boudourova-Krasteva G, Sforcin JM, Frete X, Kujumgiev A, Maimoni-Rodella R, Popov S. Phytochemical evidence for the plant origin of Brazilian propolis from São Paulo state. Z Naturforsch C, 1999; 54(5-6):401-5.

Barbosa V, Scheiffer GFC, Cardozo AGL, Pietruchinski E, Santos CZ, Silveira D, Bertocco ARP. Avaliação da atividade antibacteriana do óleo essencial de Rosmarinus officinalis $\mathrm{L}$. e tintura de própolis frente a bactéria causadora da acne Propionibacterium acnes. Rev Bras Plantas Med, 2014; 16(2):169-73.

Bennett S, Grant MM, Aldred S. Oxidative stress in vascular dementia and Alzheimer's disease: a common Pathology. J Alzheimers Dis, 2009; 17(2): 245-57.

Bhat N, Bapat S, Asawa K, Tak M, Chaturvedi P, Gupta VV, George PP. The antiplaque efficacy of propolis-based herbal toothpaste: a crossover clinical study. J Nat Sci Biol Med, 2015; 6(2):364-8.

Boisard S, Le Ray AM, Landreau A, Kempf M, Cassisa V, Flurin C, Richomme P. Antifungal and antibacterial metabolites from a French poplar type propolis. Evid Based Complement Alternat Med, 2015; 2015:319240.

Boufadi YM, Soubhye J, Riazi A, Rousseau A, Vanhaeverbeek M, Nève J, Boudjeltia KZ, Van Antwerpen P. Characterization and antioxidant properties of six Algerian propolis extracts: ethyl acetate extracts inhibit myeloperoxidase activity. Int J Mol Sci, 2014; 15:2327-45.

Bretz WA, Paulino N, Nör JE, Moreira A. The effectiveness of propolis on gingivitis: a randomized controlled trial. J Altern Complement Med, 2014; 20(12):943-8.

Brunton LL, Chabner B, Knollmann BC. Goodman and Gilman's the pharmacological basis of therapeutics. 13th edition, McGraw Hill Education, New York, NY, 2018.

Butnariu MV, Giuchici CV. The use of some nanoemulsions based on aqueous propolis and lycopene extract in the skin's protective mechanisms against UVA radiation. J Nanotechnol, 2011; 9:1-9.

Cairo do Amaral R, Gomes RT, Rocha WMS, Abreu SLR, Santos VR. Periodontitis treatment with Brazilian propolis gel. Pharmacologyonline, 2006; 3:336-41

Calegari MA, Prasniewski A, Silva CD, Sado RY, Maia FMC, Tonial LMS, Oldoni TLC. Propolis from Southwest of Parana produced by selected bees: influence of seasonality and food supplementation on antioxidant activity and phenolic profile. J Alzheimers Dis, 2009; 17(2):245-57.

Calegari MA, Prasniewski A, Silva CD, Sado RY, Maia FMC, Tonial LMS, Oldoni TLC. Propolis from Southwest of Parana produced by selected bees: influence of seasonality and food supplementation on antioxidant activity and phenolic profile. Ann Braz Acad Sci, 2017; 89(1): 45-55.

Capoci IRG, Bonfim-Mendonça PS, Arita GS, Pereira RR, Consolaro ME, Bruschi ML, Negri M, Svidzinski TI. Propolis is an efficient fungicide and inhibitor of biofilm production by vaginal Candida albicans. Evid Based Complement Alternat Med, 2015; 2015:1-9.

Chan GC, Cheung KW, Sze DM. The immunomodulatory and anticancer properties of propolis. Clin Rev Allergy Immunol, 2013; 44(3):262-73.

Choi JK, Jang YH, Lee S, Lee SR, Choi YA, Jin M, Choi JH, Park JH, Park PH, Choi H, Kwon TK, Khang D, Kim SH. Chrysin attenuates atopic dermatitis by suppressing inflammation of keratinocytes. Food Chem Toxicol, 2017; 110:142-50.

Cordeiro AR, Simioni RE, Wisniewski-Júnior A, Nunes DS. Composição química de duas variedades de própolis dos Campos Gerais do Paraná. Braz J Sustain Agric, 2015; 5:21-7.

Costa V, Moradas-Ferreira P. Oxidative stress and signal transduction in Saccharomyces cerevisiae: insights into ageing, apoptosis and diseases. Mol Aspects Med, 2001; 22:217-46.

Daleprane JB, Abdalla DS. Emerging roles of propolis: antioxidant, cardioprotective, and antiangiogenic actions. Evid-Based Complement Altern Med, 2013; 2013:1-8.

De Funari CS, Oliveira FDV, Mathor MB. Analysis of propolis from Baccharis dracunculifolia DC. (Compositae) and its effects on mouse fibroblasts. J Ethnopharmacol, 2007; 111:206-12.

De Groot AC. Propolis: a review of properties, applications, chemical composition, contact allergy, and other adverse effects. Dermatitis, 2013: 24:263-82.

Dembogurski DSO, Trentin DS, Boaretto AG, Rigo GV, da Silva RC, Tasca T, Macedo AJ, Carollo CA, Silva DB. Brown propolismetabolomic innovative approach to determine compounds capable of killing Staphylococcus aureus biofilm and Trichomonas vaginalis. Food Res Int, 2018; 111:661-73.

Dos Santos Pereira A, de Miranda Pereira AF, Trugo LC, de Aquino Neto FR. Distribution of quinic acid derivatives and other phenolic compounds in Brazilian propolis. Z Naturforsch C J Biosci, 2003; 58(78):590-3.

Dunn JH, Koo J. Psychological Stress and skin aging: a review of possible mechanisms and potential therapies. Dermatol Online J, 2013; 19(6):1-17.

Dzialo M, Mierziak J, Korzun U, Preisner M, Szorpa J, Kulma A. The potential of plant phenolics in prevention and therapy of skin disorders. Int J Mol Sci, 2016; 17(160):1-41.

Ercan N, Erdemir EO, Ozkan SY, Hendek MK. The comparative effect of propolis in two different vehicles; mouthwash and chewing-gum on plaque accumulation and gingival inflammation. Eur J Dent, 2015; 9(2):272-6.

Ferreira JM, Fernandes-Silva CC, Salatino A, Negri G, Message D. New propolis type from north-east Brazil: chemical composition, antioxidant activity and botanical origin. J Sci Food Agric, 2017; 1:1-18.

Freires IA, De Alencar SM, Rosalen PL. A pharmacological perspective on the use of Brazilian Red Propolis and its isolated compounds against human diseases. Eur J Med Chem, 2016; 110:267-79.

Garedew A, Schmolz E, Lamprecht I. Microbiological and calorimetric investigations on the antimicrobial actions of different propolis extracts: an in vitro approach. Thermochim Acta, 2004; 422:115-24.

Garrido Fernández S, Lasa Luaces E, Echechipía Modaz S, Arroabarren Alemán E, Anda Apiñániz M, Tabar Purroy AI. Allergic contact stomatitis due to therapeutic propolis. Contact Dermatitis, 2004; 50(5):321.

Gasparro FP, Mitchnick M, Nash JF. A review of sunscreen safety and efficacy. Photochem Photobiol, 1998; 68(3):243-56.

Ghaly MF, Ezzat SM, Sarhan MM. Use of propolis and ultragriseofulvin to inhibit aflatoxigenic fungi. Folia Microbiol (Praha), 1998; 43(2):156-60.

Goik U, Ptaszek A, Goik T. The influence of propolis on rheological properties of lipstick. Int J Cosmet Sci, 2015; 37(4):417-24. 
Grange JM, Davey RW. Antibacterial properties of propolis (bee glue). J R Soc Med, 1990; 83(3):159-60.

Gregoris E, Fabris S, Bertelle M, Grassato L, Stevanato R. Propolis as potential cosmeceutical sunscreen agent for its combined photoprotective and antioxidant properties. Int J Pharm, 2011; 405(1-2):97-101.

Gregory AG, Miura M, Atungulu E, Satou Y, Suzuki K. Activity of gaseous phase steam distilled propolis extracts on peroxidation and hydrolysis of rice lipids. J Food Eng, 2007; 80(3):850-8.

Gregory AG, Toshitaka U, Fumihiko T, Daisuke H. Effect of vapors from fractionated samples of propolis on microbial and oxidation damage of rice during storage. J Food Eng, 2008; 88(3):341-52.

Gu X, Zhang Q, Du Q, Shen H, Zhu Z. Pinocembrin attenuates allergic airway inflammation via inhibition of NF- $\mathrm{\kappa B}$ pathway in mice. Int Immunopharmacol, 2017; 53:90-5.

Halliwell B, Gutteridge JMC. Free radicals in biology and medicine. 4th edition, Oxford University Press, Oxford, UK, p 851, 2016.

Hamasaka T, Kumazawa S, Fujimoto T, Nakayama T. Antioxidant activity and constituents of propolis collected in various areas of Japan. Food Sci Technol Res, 2004; 10:86-92

Han MC, Durmus AS, Karabulut E, Yaman I. Effects of turkish propolis and silver sulfadiazine on burn wound healing in rats. Revue Med Vet, 2005; 156(12):624-7.

Hanieh H, Hairul Islam VI, Saravanan S, Chellappandian M, Ragul K, Durga A, Venugopal K, Senthilkumar V, Senthilkumar P, Thirugnanasambantham K. Pinocembrin, a novel histidine decarboxylase inhibitor with anti-allergic potential in in vitro. Eur J Pharmacol, 2017; 814:178-86.

Hay KD, Greig DE. Propolis allergy: a case of oral mucositis with ulceration. Oral Surg Oral Med Oral Pathol, 1990; 70:584-6.

Henschel R, Agathos M, Breit R. Occupational contact dermatitis from propolis. Contact Dermatitis, 2002: 47:52.

Hernández IM, Fernandez MC, Cuesta-Rubio O, Piccinelli AL, Rastrelli L.Polyprenylated benzophenone derivatives from Cuban propolis. J Nat Prod, 2005; 68(6):931-4.

Hozzein WN, Badr G, Al Ghamdi AA, Sayed A, Al-Waili NS, Garraud O. Topical application of propolis enhances cutaneous wound healing by promoting TGF-beta/Smad-mediated collagen production in a streptozotocin-induced type I diabetic mouse model. Cell Physiol Biochem, 2015; 37(3):940-54.

Hu F, Hepburn HR, Li Y, Chen M, Radloff SE, Daya S. Effect of ethanol and water extracts of propolis (bee glue) on acute inflammatory animal models. J Ethnopharmacol, 2005; 100(3):276-83.

Huang WJ, Huang CH, Wu CL, Lin JK, Chen YW, Lin CL, Chuang SE, Huang CY, Chen CN. Propolin G, a prenylflavanone, isolated from Taiwanese propolis, induces caspase-dependent apoptosis in brain cancer cells. J Agric Food Chem, 2007; 55(18):7366-76.

Huang S, Zhang CP, Wang K, Li GQ, Hu FL. Recent advances in the chemical composition of propolis. Molecules, 2014; 19:19610-32.

Jacob A, Parolia A, Pau A, Amalraj FD. The effects of Malaysian propolis and Brazilian red propolis on connective tissue fibroblasts in the wound healing process. BMC Complement Altern Med, 2015; 15:294

Kalogeropoulos N, Konteles SJ, Troullidou E, Mourtzinos I, Karathanos V. Chemical composition, antioxidant activity and antimicrobial properties of propolis extract from Greece and Cyprus. Food Chem, 2009;116:452-61

Kasiotis KM, Anastasiadou P, Papadopoulos A, Machera K. Revisiting Greek propolis: chromatographic analysis and antioxidant activity study. Plos one, 2017; 12(1):1-27.

Khalil ML. Biological activity of bee propolis in health and disease. Asian Pacific J Cancer Prev, 2006; 7(1):22-31.

Khayyal MT, el-Ghazaly MA, el-Khatib AS, Hatem AM, de Vries PJ, el-Shafei S, Khattab MM.

A clinical pharmacological study of the potential beneficial effects of a propolis food product as an adjuvant in asthmatic patients. Fundam Clin Pharmacol, 2003; 17(1):93-102.

Kujumgiev A, Tsvetkova I, Serkedjieva Y, Bankova V, Christov R, Popov S. Antibacterial, antifungal and antiviral activity of propolis of different geographic origin. J Ethnopharmacol, 1999; 64(3):235-40.
Lamoureux A, Meharon M, Durand AL, Darrigade AS, Doutre MS, Milpied B. A frst case of erythema multiforme-like contact dermatitis caused by propolis. Contact Dermatitis, 2017; 77:250-67.

Laskar RA, Ismail SK, Roy N, Begum NA. Antioxidant activity of Indian propolis and its chemical constituents. Food Chem, 2010; $122: 233-7$

Lima B, Tapia A, Luna L, Fabani MP, Schmeda-Hirschmann G, Podio NS, Wunderlin DA, Feresin GE. Main flavonoids, DPPH activity and metal content allow determination of the geographical origin of propolis from the province of San Juan (Argentina). J Agric Food Chem, 2009; 57:2691-8.

Marquele FD, Di Mambro VM, Georgetti SR, Casagrande R, Valim YML, Fonseca MJV. Assessment of the antioxidant activities of Brazilian extracts of propolis alone and in topical pharmaceutical formulations. J Pharm Biomed Anal, 2005; 39(3-4):455-62.

Marquele FD, Oliveira ARM, Bonato PS, Lara MG, Fonseca MJV. Propolis extract release evaluation from topical formulations by chemiluminescence and HPLC. J Pharm Biomed Anal, 2006; 41(2):461-8.

Marquele-Oliveira F, Fonseca YM, De Freitas O, Fonseca MJ. Development of topical functionalized formulations added with propolis extract: stability, cutaneous absorption and in vivo studies. Int J Pharm, 2007; 342(1-2):40-8.

Matos D, Serrano P, Brandão FM. A case of allergic contact dermatitis caused by propolis-enriched honey. Contact Dermatitis, 2014; 72:59-63

Matsuchita HLP, Matsuchita ASP. Uso da própolis na prevenção e tratamento da acne vulgar. Uniciências, 2014; 18(1):19-23.

Melliou E, Stratis E, Chinou I. Volatile constituents of propolis from various regions of Greece-antimicrobial activity. Food Chem, 2007; 103:375-80.

Mendonça ICG, Porto ICCM, Nascimento TG, Souza NS, Oliveira JMS, Arruda RES, Mousinho KC, Santos AF, Basílio-Júnio ID, Parolia A, Barreto FS. Brazilian red propolis: phytochemical screening, antioxidant activity and effect against cancer cell. BMC Complement Altern Med, 2015; 15(357):1-12.

Moon JH, Lee MY, Chung YJ, Rhee CK, Lee SJ. Effect of topical propolis on wound healing process after tonsillectomy: randomized controlled study. Clin Exp Otorhinolaryngol, 2018; 11(2):146-50.

Morawiec T, Mertas A, Wojtyczka RD, Niedzielska I, Dziedzic A, Bubiłek-Bogacz A, Sender J, Wróbel J, Tanasiewicz M, Wesołowski P, Król W. The assessment of oral microflora exposed to $3 \%$ ethanolic extract of Brazilian green propolis preparation used for hygiene maintenance following minor oral surgeries. Biomed Res Int, 2015; 2015:869575.

Moreira L, Dias LG, Pereira JA, Estevinho L. Antioxidant properties, total phenols and pollen analysis of propolis samples from Portugal. Food Chem Toxicol, 2008; 46:3482-5.

Mouhoubi-Tafinine Z, Ouchemoukh S, Tamendjari A Antioxydant activity of some algerian honey and própolis. Ind Crops Prod, 2016; 88:85-90.

Nascimento CS, Nunes LCC, Lima AAN, Grangeiro-Júnior S, Rolim-Neto PJ. Incremento do FPS em formulação de protetor solar utilizando extratos de própolis verde e vermelha. Rev Bras Farm, 2009; 90(4):334-9.

Ndiaye M, Philippe C, Mukhtar H, Ahmad N. The grape antioxidant resveratrol for skin disorders: promise, prospects, and challenges. Arch Biochem Biophys, 2011; 508(2):164-70.

Nichols JA and Katyiar SK. Skin photoprotection by natural polyphenols: anti-inflammatory, antioxidant and DNA repair mechanisms. Arch Dermatol Res, 2010; 302:71-83.

Nyman G, Hagvall L. A case of allergic contact cheilitis caused by propolis and honey. Contact Dermatitis, 2016; 74(3):186-87.

Olczyk P, Ramos P, Komosinska-Vassev K, Stojko J, Pilawa B. Positive effect of propolis on free radicals in burn wounds. Evid Based Complement Alternat Med, 2013; 2013:1-12.

Oršolić N, Skurić J, Dikić D, Stanić G. Inhibitory effect of a propolis on Di-n-Propyl Disulfide or n-Hexyl salycilate-induced skin irritation, oxidative stress and inflammatory responses in mice. Fitoterapia, 2014; 93:18-30. 
Oryan A, Alemzadeh E, Moshir A. Potential role of propolis in wound healing: biological properties and therapeutic activities. Biomed Pharmacother, 2018; 98:469-83.

Ota C, Unterkircher C, Fantinato V, Shimizu MT. Antifungal activity of propolis on different species of Candida. Mycoses, 2001; 44(910):375-8.

Park YK, Fukuda I, Ashida H, Nishiumi S, Yoshida K, Daugsch A, Sato HH, Pastore GM. Suppressive effects of ethanolic extracts from propolis and its main botanical origin on dioxin toxicity. J Agric Food Chem, 2005; 3(26): 10306-9.

Pasolini G, Semenza D, Capezzera R, Sala R, Zane C, Rodella R, Calzavara-Pinton P. Allergic contact cheilitis induced by repeated contact with propolis-enriched honey. Contact Dermatitis, 2004; 50:322-3.

Pessolato AGT, Martins DS, Ambrósio CE, Mançanares CAF, Carvalho AF. Propolis and amnion reepithelialise second-degree burns in rats. Burns, 2011; 37:1192-201.

Pietta PG. Flavonoids as antioxidants. J Nat Prod, 2000; 63:1035-42.

Popova MP, Graikou K, Chinou I, Bankova VS. GC-MS Profiling of Diterpene Compounds in Mediterranean Propolis from Greece. J Agric Food Chem, 2010; 58(5):3167-76.

Popova M, Lyoussi B, Aazza S, Antunes D, Bankova V, Miguel G. Antioxidant and $\alpha$-glucosidase inhibitory properties and chemical profiles of Moroccan propolis. Nat Prod Commun, 2015; 10(11): $1961-4$.

Rajpara S, Wilkinson MS, King CM, Gawkrodger DJ, English JS, Statham BN, Green C, Sansom JE, Chowdhury MM, Horne HL, Ormerod AD. The importance of propolis in patch - a multicentre survey. Contact Dermatitis, 2009: 61:287-90.

Roberto MM, Jamal CM, Malaspina O, Marin-Morales M. Antigenotoxicity and antimutagenicity of ethanolic extracts of Brazilian green propolis and its main botanical source determined by the Allium cepa test system. Genet Mol Biol, 2016; 39(2):257-69.

Santiago KB, Piana GM, Conti BJ, Cardoso EO, Murbach Teles Andrade BF, Zanutto MR, Mores Rall VL, Fernandes A Jr, Sforcin JM. Microbiological control and antibacterial action of a propolis-containing mouthwash and control of dental plaque in humans. Nat Prod Res, 2018;32(12):1441-5.

Santos GS, Tsutsumi S, Vieira DP, Bartolini P, Okazaki K. Effect of Brazilian propolis (AF-08) on genotoxicity, cytotoxicity and clonogenic death of Chinese hamster ovary (CHO-K1) cells irradiated with (60) Co gamma-radiation. Mutat Res Genet Toxicol Environ Mutagen, 2014; 762:17-23.

Santos NW, Yoshimura EH, Machado E, Matumoto-Pintro PT, Montanher PF, Visentainer JV. Santos GT, Zeoula LM. Antioxidant effects of a propolis extract and vitamin $\mathrm{E}$ in blood and milk of dairy cows fed diet containing flaxseed oil. Livest Sci, 2016; 191:132-8.

Savka MA, Dailey L, Popova M, Mihaylova R, Merritt B, Masek M, Le P, Nor SR, Ahmad M, Hudson AO, Bankova VI. Chemical composition and disruption of quorum sensing signaling in geographically diverse United States propolis. Evid Based Complement Alternat Med, 2015; 2015:472593.

Schmidt EM, Stock D, Chada FJG, Finger D, Sawaya ACHF, Eberlin MN, Felsner ML, Quináia SP2, Monteiro MC, Torres YR.A comparison between characterization and biological properties of Brazilian fresh and aged propolis. BioMed Res Int, 2014; 2014:257617.

Sforcin JM, Bankova V. Propolis: is there a potential for the development of new drugs. J Ethnopharmacol, 2011; 133:253-60.

Sforcin JM. Biological properties and therapeutic applications of propolis. Phytother Res, 2016; 30:894-905.

Sforcin JM, Fernandes A Jr, Lopes CA, Bankova V, Funari SR. Seasonal effect on Brazilian propolis antibacterial activity. J Ethnopharmacol, 2000; 73(1-2):243-9.
Shinmei Y, Yano H, Kagawa Y, Izawa K, Akagi M, Inoue T, Kamei C. Effect of Brazilian propolis on sneezing and nasal rubbing in experimental allergic rhinitis of mice. Immunopharmacol Immunotoxicol, 2009; 31(4):688-93.

Silva ECC, Muniz MP, Nunomura RCS. Constituintes fenólicos e atividade antioxidante da geoprópolis de duas espécies de abelha sem ferrão amazônicas. Quím Nova, 2013; 36(5):628-33.

Siqueira AB, Rodriguez LR, Santos RK, Marinho RR, Abreu S, Peixoto RF, Gurgel BC. Antifungal activity of propolis against Candida species isolated from cases of chronic periodontitis. Braz Oral Res, 2015; 29. pii: S1806-83242015000100278.

Sosa S, Bornancin A, Tubaro A, Loggia RD. Topical antiinflammation activity of an innovative aqueous formulation of Actichelated ${ }^{\mathbb{B}}$ propolis vs two commercial propolis formulation. Phytother Res, 2007; 21:823-6.

Sousa CMM, Silva HR, Vieira-Jr GM, Ayres MCC, Costa CLS, Araújo DS, Cavalcante LCD, Barros EDS, Araújo PBM, Brandão MS, Chaves MH. Fenóis totais e atividade antioxidante de cinco plantas medicinais. Quím sNova, 2007; 30(2):351-5.

Szweda P, Gucwa K, Kurzyk E, Romanowska E, DzierżanowskaFangrat K, Zielińska Jurek A, Kuś PM, Milewski S. Essential Oils, Silver Nanoparticles and propolis as alternative agents against fluconazole resistant Candida albicans, Candida glabrata and Candida krusei clinical isolates. Indian J Microbiol, 2015; 55(2):175-83.

Tiveron AP, Rosalen PL, Franchin M, Lacerda RCC, Bueno-Silva B, Benso B, Denny C, Ikegaki M, Alencar SM. Chemical characterization and antioxidant, antimicrobial, and anti-Inflammatory activities of south Brazilian organic propolis. PLoS One, 2016; 11:1-18.

Tao Y, Wang D, Hu Y, Huang Y, Yu Y, Wang D. The immunological enhancement activity of propolis flavonoids liposome in vitro and in vivo. Evid Based Complementary Altern Med, 2014; 2014:1-8.

Wagh VD. Propolis: a wonder bees product and its pharmacology potentials. Adv Pharmacol Sci, 2013; 2013:1-11.

Wang X, Sankarapandian K, Cheng Y, Woo SO, Kwon HW, Perumalsamy H, Ahn YJ. Relationship between total phenolic contents and biological properties of propolis from 20 different regions in South Korea BMC Complement Altern Med, 2016; 16:65.

Wilkinson M, Gonçalo M, Aerts O, Badulici S, Bennike NH, Bruynzeel D, Dickel H, Garcia-Abujeta JL, Giménez-Arnau AM, Hamman C, Isaksson M, Johansen JD, Mahler V, Niklasson B, Orton D, Pigatto P, Ponyai G, Rustemeyer T, Schuttelaar MLA, Spiewak R, Thyssen JP, Uter W. The European baseline series and recommended additions: 2019. Contact Dermatitis, 2019; 80(1):1-4.

Zhang J, Shen X, Wang K, Cao X, Zhang C, Zheng H, Hu F. Antioxidant activities and molecular mechanisms of the ethanol extracts of Baccharis propolis and Eucalyptus propolis in RAW64.7 cells. Pharm Biol, 2016; 54(10):2220-35.

Zhao L, Pu L, Wei L, Li J, Wu J, Xin Z, Gao W, Guo C. Brazilian green propolis improves antioxidant function in patients with type 2 diabetes mellitus. Int J Environ Res Public Health, 2016; 13:1-9.

Zilius M, Ramanauskiené K, Juskaite V, Briedis V. Formulation of propolis phenolic acids containing microemulsions and their biopharmaceutical characterization. Evid Based Complement Altern Med, 2016; 2016:1-7.

How to cite this article:

Silva MV, de Moura Jr NG, Motoyama AB, Ferreira VM. A review of the potential therapeutic and cosmetic use of propolis in topical formulations. J Appl Pharm Sci, 2020; 10(1):131-141. 